\title{
Propolis residue inclusion in the diet affects digestive enzyme activity in broiler chickens
}

\section{A inclusão do resíduo da própolis na dieta afeta a atividade de enzimas digestivas em frangos de corte}

\author{
Cristiane Regina do Amaral Duarte'; Cinthia Eyng ${ }^{2 *}$; Alice Eiko Murakami; \\ Mayra Diaz Vargas ${ }^{4}$; Ricardo Vianna Nunes ${ }^{2}$
}

\begin{abstract}
This study investigated the effects of the inclusion of solid propolis residue (PR) from alcoholic propolis extraction in the diets of broiler chickens from 1 to 21 -d of age on their performance, intestinal morphology, and digestive enzyme activity. 405 male chicks were distributed in a completely randomized design with five treatments (inclusion of $0,1,2,3$ and 4\% PR in the diets), and three replications with 27 birds each. The birds were fed experimental diets from 1 to $21-d$ of age and basal diet from 22 to 42-d of age. Feed intake (from 1 to $21-d$ and 1 to 42 -d of age) decreased linearly with increasing levels of PR inclusion $(\mathrm{P}<0.05)$. Dietary inclusion of PR did not affect intestinal morphology at 7 and 21-d of age $(\mathrm{P}>0.05)$. Pancreatic amylase activity presented a quadratic response at 7 and $21-\mathrm{d}$ of age, with its lowest activity estimated at 2.45 and $1.91 \%$ PR inclusion, respectively. At $7-d$ of age, trypsin activity decreased linearly, whereas chymotrypsin activity varied quadratically, with its activity estimated at $2.06 \%$ PR inclusion. Intestinal maltase activity varied quadratically with lowest activity predicted at $1.57 \%$ PR inclusion at 21-d of age. The dietary inclusion of solid propolis residue of propolis decreases feed intake in broilers and modulates their intestinal and pancreatic enzyme activity.
\end{abstract}

Key words: Disaccharidases. Intestinal morphometry. Pancreatic enzyme. Propolis byproduct.

\section{Resumo}

Este estudo investigou os efeitos da inclusão do resíduo sólido da extração alcoólica da própolis (PR) em dietas de frangos de corte de 1 a 21 dias de idade no desempenho, morfologia intestinal e atividade de enzimas digestivas. 405 frangos machos foram distribuídos em um delineamento inteiramente casualizado com cinco tratamentos (inclusão de $0,1,2,3$ e 4\% de PR na ração), e três repetições com 27 aves cada. As aves receberam as dietas experimentais de 1 a 21 dias de idade e dieta basal de 22 a 42 dias de idade. O consumo de ração (1 a 21 dias e 1 a 42 dias) diminuiu linearmente com o aumento de inclusão de PR $(\mathrm{P}<0,05)$. A inclusão de PR não afetou a morfometria intestinal aos $7 \mathrm{e}$ 21 dias de idade $(\mathrm{P}>0.05)$. A atividade da amilase pancreática apresentou resposta quadrática aos $7 \mathrm{e}$ 21 dias de idade $(\mathrm{P}<0,05)$, com menores atividades estimadas ao nível de 2,45 e $1,91 \%$ de inclusão de PR, respectivamente. Aos 7 dias de idade, a atividade da tripsina diminuiu linearmente, enquanto

${ }^{1}$ Prof $^{\mathrm{a}} \mathrm{Dr}^{\mathrm{a}}$, Departamento de Ciências Biológicas, Universidade do Estado de Mato Grosso, UNEMAT, Tangará da Serra, MT, Brasil. E-mail: crisrduarte@hotmail.com

2 Profs. Drs., Departamento de Zootecnia, Universidade Estadual do Oeste do Paraná, UNIOESTE, Marechal Cândido Rôndon, PR, Brasil. E-mail: cinthiaeyng@hotmail.com; nunesrv@hotmail.com

${ }^{3}$ Prof ${ }^{a}$ Dra $^{\mathrm{a}}$, Departamento de Zootecnia, Universidade Estadual de Maringá, UEM, Maringá, PR, Brasil. E-mail: aemurakami@ uem.br

${ }^{4}$ Discente, Curso de Doutorado do Programa de Pós-Graduação em Zootecnia, UEM, Maringá, PR, Brasil. E-mail: mayita154@ hotmail.com

* Author for correspondence 
a atividade da quimiotripsina variou quadraticamente, com menor atividade estimada com inclusão de $2,06 \%$ de PR. A atividade da maltase intestinal variou quadraticamente com menor atividade estimada com inclusão de 1,57\% de inclusão de PR aos 21 dias. A inclusão do resíduo sólido da própolis na dieta de frangos de corte diminui o consumo de ração e modula a atividade das enzimas digestivas intestinais e pancreáticas.

Palavras-chave: Dissacaridases. Enzimas pancreáticas. Morfometria intestinal. Subproduto da própolis.

\section{Introduction}

Propolis is a complex resinous and balsamic mixture produced by bees from plant exudates, flowers, buds, wax, pollen and the bees' salivary secretions. The chemical composition of propolis varies geographically, according to local flora, climate, season, harvesting time and bee species. Despite this variation, over 300 components in propolis have been identified, among which flavonoids, phenolics and aromatic compounds are the main constituents (SFORCIN, 2007; XU et al., 2009).

Propolis has important biological properties such as antioxidant (COTTICA et al., 2011), immunomodulatory (FREITAS et al., 2011; YUAN et al., 2012), anti-inflammatory (HORI et al., 2013), antiviral (SCHNITZLER et al., 2009) and antibacterial (FALCÃO et al., 2014) which are mainly attributed to its flavonoids and polyphenols. These compounds are extracted from propolis for use in human medicine where solvents are employed, typically grain alcohol, in order to obtain its ethanol extract. In a typical extraction, only $10 \%$ of the propolis compounds is extracted and the remaining $90 \%$ residue or waste has low market value.

The use of propolis and its derivatives have been evaluated in birds due to their biological properties, especially antibacterial, which favors the beneficial gut microbiota over pathogenic ones, and consequently improves the digestion and absorption of nutrients. Indeed, this important feature was proven through the growth of a healthy bacterial population and reduction of the harmful population in the intestine of broiler chickens (KAČÁNIOVÁ et al., 2012; KITA et al., 2014). However, propolis has active compounds that may decrease the activity of digestive enzymes, such as amylase and maltase (MATSUI et al., 2004; ZHANG et al., 2015), as validated in broilers fed crude propolis (DUARTE et al., 2014) or an ethanolic propolis extract (EYNG et al., 2014).

The effects of propolis and its by-products on animal performance remain controversial due to varying positive (DENLI et al., 2005; GALAL et al., 2008; SHALMANY; SHIVAZAD, 2006; TEKELI et al., 2011), negative (EYNG et al., 2014) and absence of effects (DUARTE et al., 2014; ZIARAN et al., 2005). Furthermore, insufficient literature is available on the use of solid propolis residue (PR) from the extraction of propolis which is expected to show effects different to those of crude propolis or an ethanolic propolis extract. Many chemical compounds are removed by ethanol extraction of propolis, such as polyphenols, decreasing the quantity of these compounds in PR. Moreover, PR contains a high level of crude energy $(5,718 \mathrm{kcal} / \mathrm{kg})$, due to its high wax quantity $(26.8 \%)$, as shown by Santos et al. (2003). However, these authors also showed that PR presents low metabolizable energy (941 $\mathrm{kcal} / \mathrm{kg}$ dry matter) for chickens because its high wax content is poorly digested.

Therefore, this study evaluated the effects of inclusion of solid propolis residue (PR) from alcoholic propolis extraction in the diets of broilers 
from 1 to $21-d$ of age on performance, intestinal morphology and digestive enzyme activities. Also, the effects of dietary inclusion of PR in broilers from 1 to $21-d$ of age on the productive performance at 42-d of age were evaluated.

\section{Material and Methods}

The protocol for this experiment was approved by Universidade Estadual de Maringá (UEM), Maringá, Paraná, Brazil (048/2010).

\section{Birds and diets}

Overall, 405 1-d-old male Cobb-Vantress ${ }^{\circledR}$ chicks were distributed in a completely randomized experimental design among three replicate pens with 27 birds of five treatments, which consisted of different levels of supplementation of the pre-starter and starter diet with PR (inclusion of 0, 1, 2, 3 and 4\% PR in the diet).

The solid propolis residue from alcoholic propolis extraction (50\% grain alcohol) used in this study was obtained from propolis (collected in several areas of the state of Paraná, Brazil and provided by Apiário Diamante Comercial Exportadora Ltda, Maringá, Paraná, Brazil). The residue was crushed and kept at 2 to $8^{\circ} \mathrm{C}$ until use in the diets. The total polyphenols in PR was determined according to Singleton and Rossi Júnior (1965) and Pierpoint (2004) and the total flavonoid content was evaluated using the aluminum chloride colorimetric method (WOISKY; SALATINO, 1998).

The broilers received the experimental diets from 1 to 21-d of age containing PR, followed by a basal diet until 42-d of age. The diets (Table 1) were based on corn and soybean meal and were formulated using the feed chemical composition values and the nutritional requirements for male broilers according to Rostagno et al. (2005).

\section{Performance}

The broilers and feed were weighed at 1,21 and 42-d of age to evaluate performance.

\section{Intestinal morphology}

At 7 and 21-d of age, 6 birds per treatment (two per pen) were selected (average weight $\pm 5 \%$ ) and euthanized by cervical dislocation to collect the small intestine. The organ was cleaned by flushing them with ice-cold saline solution $(\mathrm{NaCl}, 0.9 \%)$, dried with filter paper, and weighed (g/100 g BW) and measured $(\mathrm{cm})$.

Fragments of approximately $5 \mathrm{~cm}$ were obtained from duodenum (from the pylorus to the distal portion of the duodenal loop), jejunum (from the distal portion of the duodenal loop to Meckel's diverticulum), and ileum (the anterior portion of the ileocecal junction) to evaluate the intestinal morphology. The fragments were then placed on polystyrene sheets, opened longitudinally, washed in saline solution, fixed in 10\% formaldehyde solution, dehydrated, and embedded in paraffin. Thin sections from each segment were cut at a thickness of $5 \mu \mathrm{m}$ and stained with hematoxylin and eosin according to Luna (1968). The measurements of villus height and crypt depth were performed using a light microscope and a system that analyses computerized images (Motic Image Plus 2.0, Motic China Group Co., Hong Kong). The height of 30 villi and the depth of 30 crypts were measured from each segment and replicate. The mean was obtained for each treatment and intestinal segment from these values. 


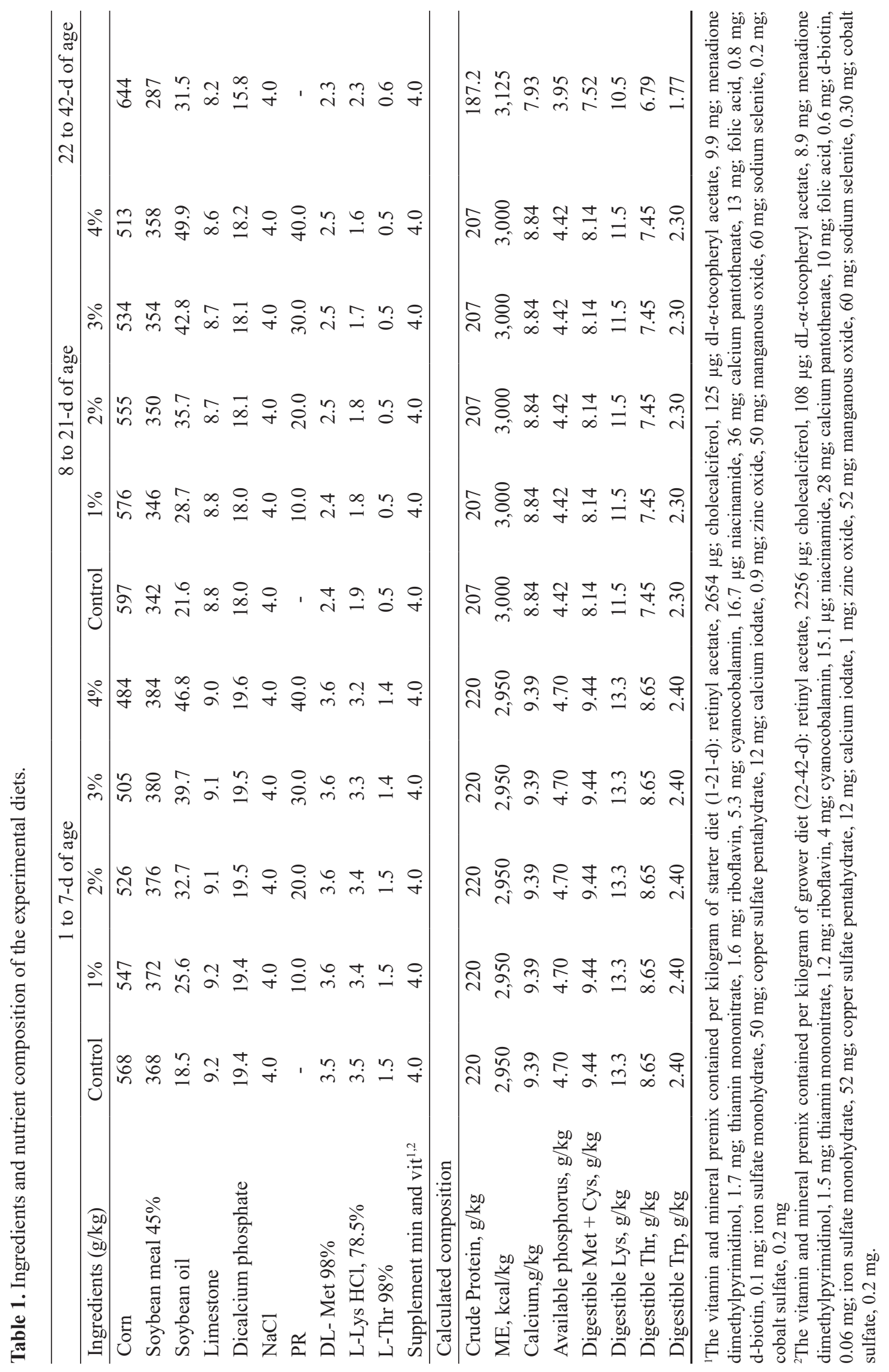




\section{Enzyme analyses}

Portions of jejunum freed of residual food and the pancreas were frozen in liquid nitrogen and stored in a freezer at $-80^{\circ} \mathrm{C}$ until assayed. The jejunum was opened longitudinally, and the mucosa was scraped off with a glass microscope coverslip to determine the activity of intestinal disaccharidases by the Dahlqvist method (DAHLQVIST, 1964). Maltase and sucrase activities were assayed by incubating aliquots of the homogenates with the appropriate substrate in malate buffer at $\mathrm{pH} 6.4$ and the amount of glucose released was determined by the glucoseoxidase method (Gold Analisa, Belo Horizonte, Minas Gerais, Brazil). The enzyme activity was expressed as units per gram of protein, which was determined by the method of Bradford (1976).

The activity of the pancreatic enzymes was measured after the whole pancreas was homogenized $(1: 20 \mathrm{wt} / \mathrm{vol})$ in $50 \mathrm{mM}$ Tris-HCl buffer ( $\mathrm{pH} 8$ ) containing $50 \mathrm{mM} \mathrm{CaCl}_{2}$ (PINHEIRO et al., 2004). The trypsin activity was determined according to the methodology described by Kakade et al. (1974). A similar method was used for the determination of chymotrypsin (ERLANGER et al., 1966). Amylase activity was determined by the iodometric method modified by Caraway (1959) (Gold Analisa, Belo Horizonte, Minas Gerais, Brazil). Lipase activity was obtained using BALB-DNTP method (Gold Analisa, Belo Horizonte, Minas Gerais, Brazil). The enzyme activity was expressed as units per amount of protein, which was determined by the method of Bradford (1976).

\section{Statistical analyses}

Pen means were used as the experimental unit for all analyses. The data were examined in relation to the PR levels using regression analysis by polynomial decomposition of the degrees of freedom. SAEG-System for Statistical and Genetic Analysis (2007) software was utilized for the analyses, and a probability of $\mathrm{P}<0.05$ was considered significant.

\section{Results}

The PR used in this study contained $11.46 \mathrm{mg} / \mathrm{kg}$ of total polyphenols and $2.57 \mathrm{mg} / \mathrm{kg}$ of flavonoids.

The feed intake of broilers supplemented with PR from 1 to 21-d and 1 to 42-d of age decreased linearly with increasing PR levels in the diet $(\mathrm{P}<0.05$, Table 2$)$, whereas the body weight gain and feed:gain ratio were similar $(\mathrm{P}>0.05)$ among all experimental groups in both periods.

The relative weight, and length of the small intestine and intestinal morphology (Table 3) of broilers did not vary with PR inclusion at either 7or 21-d of age $(\mathrm{P}>0.05)$.

At 7-d of age, the pancreatic trypsin activity decreased linearly with PR levels in the $\operatorname{diet}(\mathrm{P}<0.05$, Table 4), whereas chymotrypsin activity exhibited a quadratic response, with its lowest estimated at $2.06 \%$ PR inclusion $(\mathrm{P}<0.05)$. At 7 and $21-\mathrm{d}$ of age, pancreatic amylase activity presented a quadratic response, with lower activity estimated in broilers fed 2.45 and $1.91 \%$ PR $(\mathrm{P}<0.05)$, respectively. At 21 -d of age, maltase activity in the jejunum varied quadratically; the quadratic equation predicted a lower maltase activity in broilers fed $1.57 \%$ PR $(\mathrm{P}<0.05$, Table 4). 
Table 2. The performance of broiler chickens from 1 to $42-\mathrm{d}$ of age fed with diets containing different levels of propolis residue (PR) from 1 to 21 -d of age.

\begin{tabular}{|c|c|c|c|}
\hline Levels of PR & Weight gain, $g$ & Feed intake, $g$ & Feed:Gain ratio \\
\hline \multicolumn{4}{|c|}{ From 1 to 7 -d of age } \\
\hline $0 \%$ & $168.90 \pm 4.09$ & $231.29 \pm 2.61$ & $1.37 \pm 0.03$ \\
\hline $1 \%$ & $161.91 \pm 7.44$ & $226.99 \pm 2.91$ & $1.41 \pm 0.07$ \\
\hline $2 \%$ & $159.01 \pm 2.29$ & $228.01 \pm 6.94$ & $1.43 \pm 0.02$ \\
\hline $3 \%$ & $162.65 \pm 7.05$ & $223.88 \pm 6.75$ & $1.38 \pm 0.02$ \\
\hline $4 \%$ & $167.17 \pm 3.33$ & $224.27 \pm 3.06$ & $1.34 \pm 0.04$ \\
\hline \multirow{3}{*}{$\begin{array}{l}\text { Regression } \\
\text { (p-value) }\end{array}$} & L: 0.75 & L: 0.24 & L: 0.57 \\
\hline & Q: 0.15 & Q: 0.80 & Q: 0.14 \\
\hline & \multicolumn{3}{|c|}{ From 1 to $21-\mathrm{d}$ of age } \\
\hline $0 \%$ & $893.50 \pm 15.57$ & $1335.00 \pm 10.97$ & $1.49 \pm 0.02$ \\
\hline $1 \%$ & $839.45 \pm 31.58$ & $1252.10 \pm 10.70$ & $1.49 \pm 0.04$ \\
\hline $2 \%$ & $889.25 \pm 21.31$ & $1303.52 \pm 30.28$ & $1.47 \pm 0.01$ \\
\hline $3 \%$ & $827.80 \pm 2.92$ & $1251.82 \pm 43.33$ & $1.51 \pm 0.05$ \\
\hline $4 \%$ & $885.44 \pm 28.25$ & $1265.52 \pm 18.24$ & $1.43 \pm 0.02$ \\
\hline \multirow{3}{*}{$\begin{array}{l}\text { Regression } \\
\text { (p-value) }\end{array}$} & L: 0.72 & L: $0.04^{1}$ & L: 0.19 \\
\hline & Q: 0.25 & Q: 0.25 & Q: 0.51 \\
\hline & \multicolumn{3}{|c|}{ From 1 to $42-d$ of age } \\
\hline $0 \%$ & $2883.71 \pm 6.74$ & $5237.52 \pm 24.72$ & $1.82 \pm 0.01$ \\
\hline $1 \%$ & $2716.64 \pm 39.17$ & $5027.18 \pm 35.19$ & $1.85 \pm 0.01$ \\
\hline $2 \%$ & $2870.44 \pm 34.94$ & $5155.57 \pm 53.79$ & $1.80 \pm 0.02$ \\
\hline $3 \%$ & $2795.29 \pm 36.66$ & $5036.77 \pm 65.46$ & $1.80 \pm 0.03$ \\
\hline $4 \%$ & $2812.98 \pm 36.36$ & $5045.13 \pm 54.10$ & $1.79 \pm 0.01$ \\
\hline \multirow{2}{*}{$\begin{array}{l}\text { Regression } \\
\text { (p-value) }\end{array}$} & L: 0.34 & $\mathrm{~L}: 0.01^{2}$ & L: 0.10 \\
\hline & Q: 0.19 & Q: 0.25 & Q: 0.60 \\
\hline
\end{tabular}

Values are means of 3 replicate pens per treatment, with each pen having 27 birds at 1 -d of age \pm standard error

Values corrected for mortality

L: Linear regression; Q: quadratic regression

${ }^{1} \mathrm{Y}=1313.70-14.7568 \mathrm{x}, \mathrm{R}^{2}=0.47$.

${ }^{2} \mathrm{Y}=5185.81-40.9651 \mathrm{x}, \mathrm{R}^{2}=0.40$.

The pancreatic lipase and jejunal sucrase included in the $\operatorname{diet}(\mathrm{P}>0.05)$. activity at 7 or $21-d$ of age did not vary with PR 


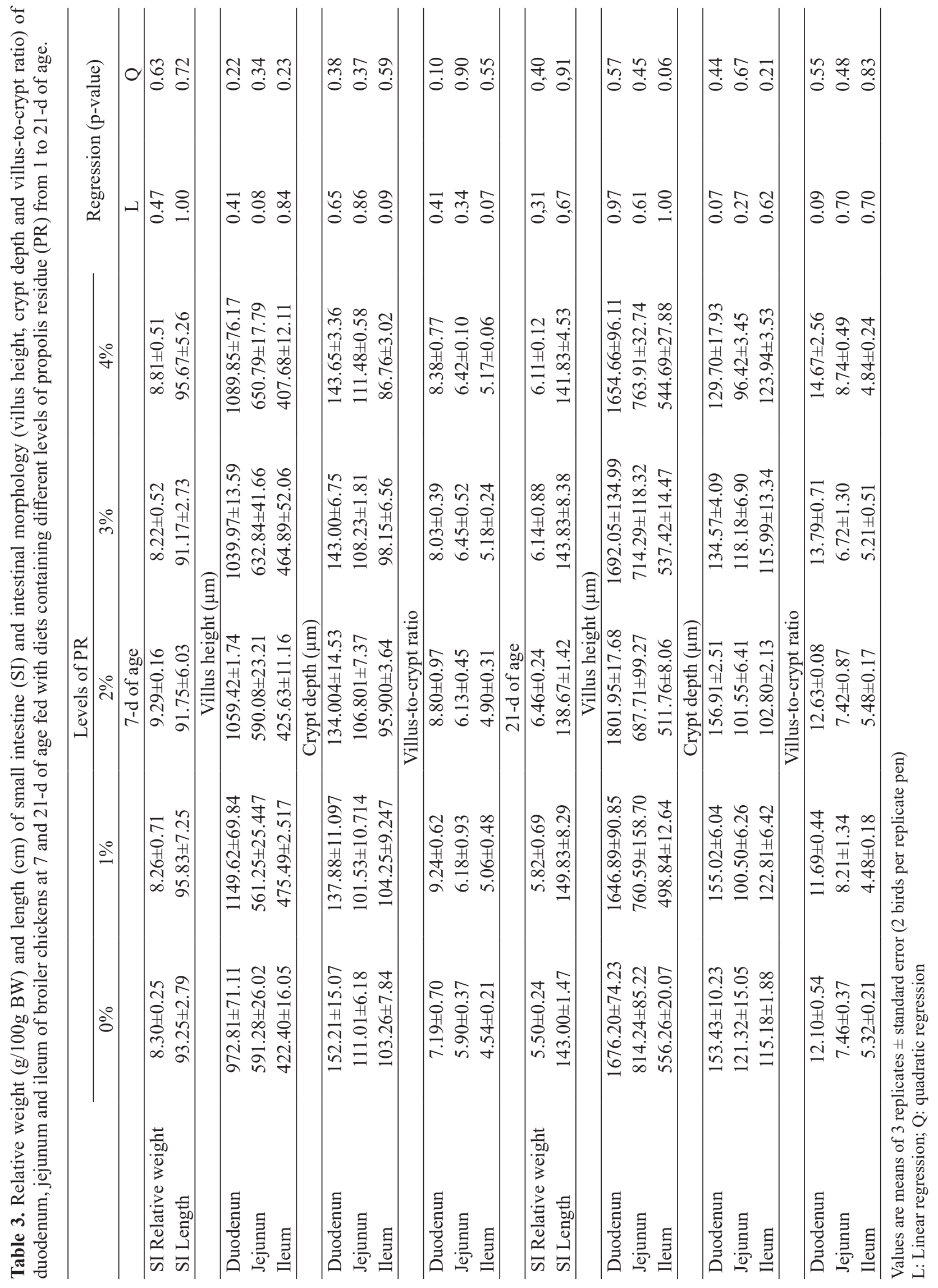


Table 4. Sucrase and maltase activity in the jejunum and amylase, trypsin, chymotrypsin and lipase activities in pancreas of broiler chickens at 7 and 21-d of age fed with diets containing different levels of propolis residue (PR) from 1 to 21 -d of age.

\begin{tabular}{|c|c|c|c|c|c|c|}
\hline & \multicolumn{2}{|c|}{ Intestinal disaccharidases } & \multicolumn{4}{|c|}{ Pancreatic enzymes } \\
\hline Levels of PR & $\begin{array}{c}\text { Sucrase } \\
\text { (U/mg protein) }\end{array}$ & $\begin{array}{c}\text { Maltase } \\
\text { (U/mg protein) }\end{array}$ & $\begin{array}{l}\text { Amylase } \\
(\mathrm{UA} / \mu \mathrm{g} \\
\text { protein) }\end{array}$ & $\begin{array}{c}\text { Trypsin } \\
(\mathrm{nmol} / \mu \mathrm{g} \\
\text { protein) }\end{array}$ & $\begin{array}{c}\text { Chymotrypsin } \\
\text { (nmol/ } \mu \mathrm{g} \\
\text { protein) }\end{array}$ & $\begin{array}{l}\text { Lipase } \\
\text { (UI/mg } \\
\text { protein) } \\
\end{array}$ \\
\hline & & & 7-d of age & & & \\
\hline $0 \%$ & $4.83 \pm 0.53$ & $21.13 \pm 1.41$ & $10.20 \pm 0.57$ & $23.76 \pm 0.89$ & $5.30 \pm 1.22$ & $25.94 \pm 0.67$ \\
\hline $1 \%$ & $4.62 \pm 0.06$ & $18.26 \pm 2.72$ & $4.89 \pm 0.94 *$ & $37.52 \pm 3.67^{*}$ & $3.63 \pm 0.79$ & $20.53 \pm 2.61$ \\
\hline $2 \%$ & $4.60 \pm 0.78$ & $17.66 \pm 1.84$ & $4.69 \pm 0.62 *$ & $18.23 \pm 1.64$ & $3.02 \pm 0.43$ & $23.38 \pm 0.67$ \\
\hline $3 \%$ & $4.15 \pm 0.25$ & $19.04 \pm 1.77$ & $6.28 \pm 0.18^{*}$ & $12.81 \pm 0.42^{*}$ & $4.54 \pm 0.12$ & $25.96 \pm 3.26$ \\
\hline $4 \%$ & $3.57 \pm 0.51$ & $17.03 \pm 2.09$ & $5.58 \pm 0.02 *$ & $18.72 \pm 1.33$ & $4.50 \pm 0.52$ & $23.16 \pm 1.64$ \\
\hline \multirow{2}{*}{$\begin{array}{c}\text { Regression } \\
\text { (p-value) }\end{array}$} & L: 0.07 & L: 0.27 & $\mathrm{~L}:<0.01$ & $\mathrm{~L}:<0.01^{4}$ & L: 0.75 & L: 1.00 \\
\hline & Q: 0.54 & Q: 0.68 & $\mathrm{Q}:<0.01^{2}$ & Q: 0.81 & Q: $0.03^{5}$ & Q: 0.53 \\
\hline \multicolumn{7}{|c|}{ 21-d of age } \\
\hline $0 \%$ & $6.85 \pm 0.48$ & $28.13 \pm 1.56$ & $7.01 \pm 1.39$ & $21.63 \pm 10.82$ & $4.23 \pm 1.33$ & $21.85 \pm 2.34$ \\
\hline $1 \%$ & $7.81 \pm 0.07$ & $27.12 \pm 0.08$ & $1.89 \pm 0.01 *$ & $13.29 \pm 3.47$ & $3.49 \pm 0.74$ & $21.53 \pm 6.32$ \\
\hline $2 \%$ & $6.13 \pm 0.59$ & $21.47 \pm 1.12 *$ & $2.34 \pm 1.02 *$ & $19.64 \pm 1.69$ & $5.12 \pm 1.06$ & $23.23 \pm 4.87$ \\
\hline $3 \%$ & $6.09 \pm 0.98$ & $29.15 \pm 0.70$ & $2.71 \pm 0.38^{*}$ & $14.98 \pm 3.58$ & $5.50 \pm 0.91$ & $26.48 \pm 0.88$ \\
\hline $4 \%$ & $7.37 \pm 0.30$ & $33.57 \pm 0.07 *$ & $8.14 \pm 0.91$ & $9.51 \pm 1.57$ & $5.09 \pm 1.31$ & $26.03 \pm 2.08$ \\
\hline \multirow{2}{*}{$\begin{array}{c}\text { Regression } \\
(\mathrm{p} \text {-value })\end{array}$} & L: 0.78 & L: 0.04 & L: 0.94 & L: 0.14 & L: 0.37 & L: 0.35 \\
\hline & Q: 0.47 & $\mathrm{Q}:<0.01^{1}$ & $\mathrm{Q}:<0.001^{3}$ & Q: 0.65 & Q: 0.84 & Q: 0.91 \\
\hline
\end{tabular}

Values are means of 3 replicates \pm standard error ( 2 birds per replicate pen)

$\mathrm{U}$ : units of respective enzyme: one mol of substrate hydrolyzed per minute

UA: amylase unit; amount of enzyme that hydrolyzes $10 \mathrm{mg}$ of starch in $30 \mathrm{~min}$

UI: international unit of lipase activity, amount of enzyme that catalyzes the liberation of $1 \mu \mathrm{mol}$ of fatty acid released per min

L: Linear regression; Q: quadratic regression

${ }^{1} \mathrm{Y}=28.4164-5.14032 \mathrm{x}+1.63928 \mathrm{x}^{2}, \mathrm{R}^{2}=0,76$; Min.point: 1.57 .

${ }^{2} \mathrm{Y}=9.58202-4.2888 \mathrm{x}+0.876239 \mathrm{x}^{2}, \mathrm{R}^{2}=0.77$; Min.point: 2.45 .

${ }^{3} \mathrm{Y}=6.88944-5.82265 \mathrm{x}+1.52437 \mathrm{x}^{2}, \mathrm{R}^{2}=0.95$; Min.point: 1.91 .

${ }^{4} \mathrm{Y}=29.1699-3.48007 \mathrm{x}, \mathrm{R}^{2}=0.34$.

${ }^{5} \mathrm{Y}=5.13104-1.73391 \mathrm{x}+0.41989 \mathrm{x}^{2}, \mathrm{R}^{2}=0.78$; Min.point: 2.06 .

\section{Discussion}

The inclusion of propolis products and its byproducts in poultry feed have been studied due to the presence of important compounds, such as phenolic acids and flavonoids and their effects on animal physiology. Although propolis has shown beneficial effects in human and animal health by acting as an antioxidant (COTTICA et al., 2011), antimicrobial (FALCÃO et al., 2014) and antiviral (SCHNITZLER et al., 2009), for example, there is no consensus regarding its beneficial effects on poultry performance. Improvements in poultry performance by propolis and its products have been demonstrated in several studies (DENLI et al., 2005; GALAL et al., 2008; SHALMANY; SHIVAZAD, 2006; TEKELI et al., 2011), whereas Eyng et al. (2014) showed a decrease in body weight gain and feed intake when broilers from 1 to $7-\mathrm{d}$ of age fed ethanolic propolis extract. The controversial effects presented in the literature can be attributed to the difficulty in standardizing propolis products due to varying composition according to location and time of collection, notwithstanding the additional complexity when it is incorporated into other products, by the various processing methods available. 
Regarding the propolis processing to obtain ethanolic propolis extract for use in human medicine, active compounds are extracted with solvents, mainly grain alcohol. This processing generates a solid residue with a lower concentration of polyphenols and flavonoids and a higher wax content than crude propolis and ethanolic propolis extract. This study focused on the positive attributes of propolis. Hence, the polyphenol and flavonoid composition was evaluated due to the beneficial properties, attributed to these compounds, despite their substantial removal from PR by the extraction processing. Indeed, in comparison to our previous studies with propolis extract (EYNG et al., 2014) and crude propolis (DUARTE et al., 2014), PR showed a lower concentration of these compounds. Despite the different compositions of propolis products and its residues, their comparison is relevant due to the limited literature concerning composition and use of PR in poultry feed. Santos et al. (2003) showed a low metabolizable energy of PR in chickens (941 kcal/kg dry matter) despite its high crude energy $(5,718 \mathrm{kcal} / \mathrm{kg})$, due to a high wax content. Wax is assumed to be poorly digested by mammals and broilers (PLACE, 1992), probably due to digestive enzymes, i.e., pancreatic lipasecolipase lipolytic system, which are inefficient at hydrolyzing wax esters (PLACE, 1992) and the inability of intestinal microbiota to degrade it. Some chemical characteristics of wax, such as its high melting point and water insolubility and hydrophobic characteristic, are responsible for its indigestibility (LEE; PATTON, 1989).

The dietary inclusion of $4 \% \mathrm{PR}$ in broilers from 1 to $21-\mathrm{d}$ of age and 1 to $42-\mathrm{d}$ of age decreased feed intake by 5.2 and $3.7 \%$, respectively, compared to those fed a diet without PR. The dietary inclusion of PR did not affect body weight gain or feed:gain ratio in chickens. Although propolis contains resins, waxes and honey, which are considered palatable, and can increase feed intake (SHALMANY; SHIVAZAD, 2006; TATLI SEVEN et al., 2008), the decreased feed intake in this study can be attributed to the high amount of wax esters in PR, which are considered nutritionally satiating (MEYER et al., 1998). The absence of beneficial effects on broiler performance in the initial stage may be due to the decreased content of active compounds in the PR, in addition to the above mentioned high wax content. Our previous study showed that addition of 100-500 ppm crude propolis to the diets of broiler from 1 to 21-d of age did not affect broiler performance despite small changes in intestinal morphophysiology (DUARTE et al., 2014). Crude propolis, as well as its residue, may not provide sufficient nutritional intake of biological components because they are combined with the wax. Conversely, the inclusion of ethanolic propolis extract impaired broiler performance in the pre-initial phase, probably due to the decreased sucrase activity, whereas in 21-d old chickens, its inclusion improved intestinal morphology and sucrase response (EYNG et al., 2014), probably due to the high availability of key active compounds.

Although PR inclusion did not influence the intestinal morphology of broilers in the pre-initial and initial phases, digestive enzyme activity was affected, particularly pancreatic activity. Furthermore, it was observed that the effect on pancreatic enzymate activity was most evident in 7-d of old broilers, as shown by the influence on amylase, trypsin and chymotrypsin activities. This age is crucial for broiler development, as, once the chick hatches, the gastrointestinal tract rapidly develops in relation to their body development and is colonized by microbial populations, which may or may not be beneficial (GONG et al., 2008).

At 7 -d of age, amylase activity showed a quadratic response with the lowest activity estimated in broilers fed $2.45 \%$ PR inclusion and at $21-\mathrm{d}$ of age, the amylase and maltase activities varied quadratically with their lowest activities predicted at 1.91 and $1.57 \%$ PR inclusion, respectively. This result was comparable to the inclusion of crude propolis (DUARTE et al., 2014), which showed that pancreatic amylase activity decreased with 
dietary inclusion of crude propolis, possibly related to the inhibitory effect of propolis polyphenols on amylase and maltase activity (MATSUI et al., 2004; ZHANG et al., 2015), despite the low concentration of these compounds in the residue. Many authors have shown that amylase and maltase activity may be decreased by anthocyanins, phenolic acids, and flavonoids (FORESTER et al., 2012; HANHINEVA et al., 2010; MCDOUGALL et al., 2005). This is due to either non-competitive inhibition associated with the number of hydroxyl groups on the B-ring of the flavonoid skeleton, and consequent formation of hydrogen bonds between the hydroxyl groups of the polyphenol ligands and catalytic site of the enzyme (LO PIPARO et al., 2008), or the antioxidant properties of the polyphenols, which may also inhibit amylase activity (HASHIM et al., 2013). Moreover, propolis can regulate intestinal microbiota, favouring the colonization of beneficial bacteria and limiting the presence of pathogenic bacteria (ABDEL-MOHSEIN et al., 2014; KAČÁNIOVÁ et al., 2012; KITA et al., 2014), which can promote intestinal health, and consequently, increase the intestinal digestive and absorptive ability. This effect can be attributed to flavonoids, as they prevent pathogenic bacteria from adhering to the intestinal epithelium (MARÍN et al., 2015; PARKAR et al., 2008).

In broilers at 7-d of age, chymotrypsin activity showed a quadratic response according to the PR inclusion levels, with the lowest predicted activity at $2.06 \%$ PR inclusion, while trypsin activity decreased linearly. There is no evidence in the literature that propolis affects either trypsin or chymotrypsin activity, although trypsin activity may be inhibited by procyanidins, such as tannins (GONÇALVES et al., 2011).

\section{Conclusion}

The inclusion of 1 to $4 \%$ solid propolis residue in the diets of broilers from 1 to $21-\mathrm{d}$ of age decreases feed intake and modulates the digestive enzyme activity without affecting body weight gain, feed:gain ratio or intestinal morphology.

\section{Acknowledgments}

The authors gratefully acknowledge the financial support for this study by National Counsel of Technological and Scientific Development (CNPq, Brazil) and the Coordination for the Improvement of Higher Education Personnel (CAPES, Brazil).

\section{References}

ABDEL-MOHSEIN, H. S.; MAHMOUD, M. A. M.; MAHMOUD, U. T. Influence of propolis on intestinal microflora of Ross broilers exposed to hot environment. Advances in Animal and Veterinary Sciences, Lahore, v. 2, n. 4, p. 204-211, abr. 2014.

BRADFORD, M. M. A rapid and sensitive method for the quantitation of microgram quantities of protein utilizing the principle of protein-dye binding. Analytical Biochemistry, New York, v. 72, n. 1-2, p. 248-254, maio 1976.

CARAWAY, W. T. A stable starch substrate for the determination of amylase in serum and other body fluids. American Journal of Clinical Pathology, Oxford, v. 32, n. 1, p. 97-99, jul. 1959.

COTTICA, S. M.; SAWAYA, A. C. H. F.; EBERLIN, M. N.; FRANCO, S. L.; ZEOULA, L. M.; VISENTAINER, J. V. Antioxidant activity and composition of propolis obtained by different methods of extraction. Journal of the Brazilian Chemical Society, São Paulo, v. 22, n. 5, p. 929-935, maio 2011.

DAHLQVIST, A. Method for assay of intestinal disaccharidases. Analytical Biochemistry, New York, v. 7, n. 1, p. 18-25, jan. 1964.

DENLI, M.; CANKAYA, S.; SILICI, S.; OKAN, F.; ULUOCAK, A. N. Effect of dietary addition of Turkish propolis on the growth performance, carcass characteristics and serum variables of quail (Coturnix coturnix japonica). Asian-Australasian Journal of Animal Sciences, Seoul, v. 18, n. 6, p. 848-854, jun. 2005.

DUARTE, C. R. A.; EYNG, C.; MURAKAMI, A. E.; SANTOS, T. C. Intestinal morphology and activity of digestive enzymes in broilers fed crude propolis. Canadian Journal of Animal Science, Ottawa, v. 94, n. 1, p. 105-114, mar. 2014. 
ERLANGER, B. F.; EDEL, F.; COOPER, A. G. The action of chymotrypsin on two new chromogenic substrates. Archives of Biochemistry and Biophysics, New York, v. 115, n. 1, p. 206-210, jul. 1966.

EYNG, C.; MURAKAMI, A. E.; DUARTE, C. R. A.; SANTOS, T. C. Effect of dietary supplementation with an ethanolic extract of propolis on broiler intestinal morphology and digestive enzyme activity. Journal of Animal Physiology and Animal Nutrition, Berlin, v. 98, n. 2, p. 393-401, abr. 2014.

FALCÃO, S. I.; VALE, N.; COS, P.; GOMES, P.; FREIRE, C.; MAES, L.; VILAS-BOAS, M. In vitro evaluation of Portuguese propolis and floral sources for antiprotozoal, antibacterial and antifungal activity. Phytotherapy Research, London, v. 28, n. 3, p. 437-443, mar. 2014.

FORESTER, S. C.; GU, Y.; LAMBERT, J. D. Inhibition of starch digestion by the green tea polyphenol, (-)-epigallocatechin-3-gallate. Molecular Nutrition \& Food Research, Weinheim, v. 56, n. 11, p. 1647-1654, nov. 2012.

FREITAS, J. A.; VANAT, N.; PINHEIRO, J. W.; BALARIN, M. R.; SFORCIN, J. M.; VENANCIO, E. J. The effects of propolis on antibody production by laying hens. Poultry Science, Oxford, v. 90, n. 6, p. 1227-1233, jun. 2011.

GALAL, A.; ABD EL-MOTAAL, A. M.; AHMED, A. M. H.; ZAKI, T. G. Productive performance and immune response of laying hens as affected by dietary propolis supplementation. International Journal of Poultry Science, Faisalabad, v. 7, n. 3, p. 272-278, mar. 2008.

GONÇALVES, R.; MATEUS, N.; PIANET, I.; LAGUERRE, M.; FREITAS, V. de. Mechanisms of tannin-induced trypsin inhibition: a molecular approach. Langmuir, Washington, v. 27, n. 21, p. 13122-13129, ago. 2011.

GONG, J.; YU, H.; LIU, T.; GILL, J. J.; CHAMBERS, J. R.; WHEATCROFT, R.; SABOUR, P. M. Effects of zinc bacitracin, bird age and access to range on bacterial microbiota in the ileum and caeca of broiler chickens. Journal of Applied Microbiology, Oxford, v. 104, n. 5, p. 1372-1382, maio 2008.

HANHINEVA, K.; TÖRRÖNEN, R.; BONDIAPONS, I.; PEKKINEN, J.; KOLEHMAINEN, M.; MYKKÄNEN, H.; POUTANEN, K. Impact of dietary polyphenols on carbohydrate metabolism. International Journal of Molecular Sciences, Basel, v. 11, n. 4, p. 1365-1402, mar. 2010.

HASHIM, A.; KHAN, M. S.; KHAN, M. S.; BAIG, M. H.; AHMAD, S. Antioxidant and $\alpha$-amylase inhibitory property of Phyllanthus virgatus L.: an in vitro and molecular interaction study. BioMed Research International, New York, v. 2013, n. 729393, p. 1-12, 2013. Available at: <http://dx.doi.org/10.1155/2013/ 729393>. Accessed at: 19 abr. 2016.

HORI, J. I.; ZAMBONI, D. S.; CARRÃO, D. B.; GOLDMAN, G. H.; BERRETTA, A. A. The inhibition of inflammasomes by Brazilian propolis (EPP-AF). Evidence-Based Complementary and Alternative Medicine, Oxford, v. 2013, n. 418508, p. 1-11, 2013. Available at: <http://www.hindawi.com/journals/ ecam/2013/418508/>. Accessed at: 19 abr. 2016.

KAČÁNIOVÁ, M.; ROVNÁ, K.; ARPÁŠOVÁ, H.; CUBOŇ, J.; HLEBA, L.; POCHOP, J.; KUNOVÁ, S.; HAŠČÍK, P. In vitro and in vivo antimicrobial activity of propolis on the microbiota from gastrointestinal tract of chickens. Journal of Environmental Science and Health. Part A, Toxic/Hazardous Substances \& Environmental Engineering, London, v. 47, n. 11, p. 1665-1671, set. 2012.

KAKADE, M. L.; RACKIS, J. J.; MCGHEE, J. E.; PUSKI, G. Determination of trypsin inhibitor activity of soy products: a collaborative analysis of an improved procedure. Cereal Chemistry, Saint Paul, v. 51, n. 3, p. 376-382, maio/jun. 1974.

KITA, K.; KEN, I. R.; AKAMINE, C.; KAWADA, W.; SHIMURA, Y.; INAMOTO, T. Influence of propolis residue on the bacterial flora in the cecum of $\mathrm{Nanbu}$ Kashiwa. The Journal of Poultry Science, Ibaraki, v. 51, n. 3, p. 275-280, jul. 2014.

LEE, R. F.; PATTON, J. S. Alcohol and waxes. In: ACKMAN, R. G. Marine biogenic lipids, fats, and oils. Boca Raton: CRC Press, 1989. v. 1, p. 73-102.

LO PIPARO, E.; SCHEIB, H.; FREI, N.; WILLIAMSON, G.; GRIGOROV, M.; CHOU, C. J. Flavonoids for controlling starch digestion: structural requirements for inhibiting human $\alpha$-amylase. Journal of Medicinal Chemistry, Washington, v. 51, n. 12, p. 3555-3561, jun. 2008.

LUNA, L. G. Manual of histologic staining methods of the armed forces institute of pathology. $3^{\text {th }}$ ed. New York: McGraw-Hill Book, 1968. 258 p.

MARÍN, L.; MIGUÉLEZ, E. M.; VILLAR, C. J.; LOMBÓ, F. Bioavailability of dietary polyphenols and gut microbiota metabolism: antimicrobial properties. BioMed Research International, New York, v. 2015, n. 905215, p. 1-18, 2015. Available at: <http://dx.doi. org/10.1155/2015/905215>. Accessed at: 19 abr. 2016.

MATSUI, T.; EBUCHI, S.; FUJISE, T.; ABESUNDARA, K. J.; DOI, S.; YAMADA, H.; MATSUMOTO, K. Strong 
antihyperglycemic effects of water-soluble fraction of Brazilian propolis and its bioactive constituent, 3,4,5-triO-caffeoylquinic acid. Biological \& Pharmacentical Bulletin, Tokyo, v. 27, n. 11, p. 1797-1803, nov. 2004.

MCDOUGALL, G. J.; SHPIRO, F.; DOBSON, P.; SMITH, P.; BLAKE, A.; STEWART, D. Different polyphenolic components of soft fruits inhibit $\alpha$-amylase and $\alpha$-glucosidase. Journal of Agricultural and Food Chemistry, Washington, v. 53, n. 7, p. 2760-2766, mar. 2005.

MEYER, J. H.; HLINKA, M.; TABRIZI, Y.; DIMASO, N.; RAYBOULD, H. E. Chemical specificities and intestinal distributions of nutrient-driven satiety. American Journal of Physiology - Regulatory, Integrative and Comparatie Physiology, Bethesda, v. 275, n. 4, p. R1293-R1307, out. 1998.

PARKAR, S. G.; STEVENSON, D. E.; SKINNER, M. A. The potential influence of fruit polyphenols on colonic microflora and human gut health. International Journal of Food Microbiology, Amsterdam, v. 124, n. 3, p. $295-$ 298, jun. 2008.

PIERPOINT, W. S. The extraction of enzymes from plant tissues rich in phenolic compounds. In: CUTLER, P. (Ed.). Methods in molecular biology. $2^{\text {nd }}$ ed. Clifton: Humana Press, 2004. v. 244, p. 65-74.

PINHEIRO, D. F.; CRUZ, V. C.; SARTORI, J. R.; VICENTINI-PAULINO, M. L. Effect of early feed restriction and enzyme supplementation on digestive enzyme activities in broilers. Poultry Science, Oxford, v. 83, n. 9, p. 1544-1450, set. 2004.

PLACE, A. R. Comparative aspects of lipid digestion and absorption: physiological correlates of wax ester digestion. American Journal of Physiology, Washington, v. 263, n. 3, p. R464-R471, set. 1992.

ROSTAGNO, H. S.; ALBINO, L. F. T.; DONZELE, J. L.; GOMES, P. C.; OLIVEIRA, R. F.; LOPES, D. C.; FERREIRA, A. S.; BARRETO, S. L. T. Tabelas brasileiras para aves e suínos: composição de alimentos e exigências nutricionais. $2^{\text {nd }}$ ed. Viçosa, MG: Editora UFV, 2005. 186 p.

SANTOS, A. V.; TEIXEIRA, A. S.; RODRIGUES, P. B.; FREITAS, R. T. F.; GUIMARÃES, A. M.; GIACOMETTI, R. A. Valor nutritivo do resíduo de própolis para frangos de corte. Ciência e Agrotecnologia, Lavras, v. 27, n. 5, p. 1152-1159, set./out. 2003.

SCHNITZLER, P.; NEUNER, A.; NOLKEMPER, S.; ZUNDEL, C.; NOWACK, H.; SENSCH, K. H.; REICHLING, J. Antiviral activity and mode of action of propolis extracts and selected compounds. Phytotherapy Research, London, v. 24, n. S1, p. S20-S28, jan. 2009.
SFORCIN, J. M. Propolis and the imune system: a review. Journal of Ethnopharmacology, Lausanne, v. 113, n. 1, p. 1-14, ago. 2007.

SHALMANY, S. K.; SHIVAZAD, M. The effect of diet propolis supplementation on ross broiler chicks performance. International Journal of Poultry Science, Faisalabad, v. 5, n. 1, p. 84-88, jan. 2006.

SINGLETON, V. L.; ROSSI JÚNIOR, J. A. Colorimetry of total phenolics with phosphomolybdicphosphotungstic acid reagents. American Journal of Enology and Viticulture, Davis, v. 16, n. 3, p. 144-158, jul. 1965.

SISTEMA PARA ANÁLISES ESTATÍSTICAS - SAEG. Sistema para análises estatísticas. SAEG 9.1. Viçosa, MG: Fundação Arthur Bernardes, UFV, 2007.

TATLI SEVEN, P.; SEVEN, I.; YILMAZ, M.; ŞIMŞEK, Ü. G. The effects of Turkish propolis on growth and carcass characteristics in broilers under heat stress. Animal Feed Science and Technology, Amsterdam, v. 146, n. 1-2, p. 137-148, set. 2008.

TEKELI, A.; KUTLU, H. R.; CELIK, L. Effects of $Z$. officinale and propolis extracts on the performance, carcass and some blood parameters of broiler chicks. Current Research in Poultry Science, New York, v. 1, n. 1, p. 12-23, jan. 2011.

WOISKY, R. G.; SALATINO, A. Analysis of propolis: some parameters and procedures for chemical quality control. Journal of Apicultural Research, Gerrards Cross, v. 37, n. 2, p. 99-105, mar. 1998.

XU, Y.; LUO, L.; CHEN, B.; FU, Y. Recent development of chemical components in propolis. Frontiers of Biology in China, Beijing, v. 4, n. 4, p. 385-391, dez. 2009.

YUAN, J.; LIU, J.; HU, Y.; FAN, Y.; WANG, D.; GUO, L.; NGUYEN, T. L.; ZHAO, X.; LIU, X.; LIU, C.; WU, $\mathrm{Y}$. The immunological activity of propolis flavonoids liposome on the immune response against ND vaccine. International Journal of Biological Macromolecules, Guildford, v. 51, n. 4, p. 400-405, jun. 2012.

ZHANG, H.; WANG, G.; BETA, T.; DONG, J. Inhibitory properties of aqueous ethanol extracts of propolis on alpha-glucosidase. Evidence-Based Complementary and Alternative Medicine, Oxford, v. 2015, n. 587383, p. 1-7, 2015. Available at: <http://dx.doi. org/10.1155/2015/587383>. Accessed at: 19 abr. 2016.

ZIARAN, H. R.; RAHMANI, H. R.; POURREZA, J. Effect of dietary oil extract of propolis on immune response and broiler performance. Pakistan Journal of Biological Sciences, Faisalabad, v. 8, n. 10, p. 14851490, set. 2005. 